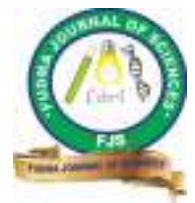

\title{
SPECIATION OF METALS IN SEDIMENTS FROM DAMS AND RIVERS ALONG GOLD MINING VICINITIES IN ZAMFARA STATE
}

\author{
Moses SUNDAY \\ Department of Basic and Preliminary Studies, School of General Studies, Federal Polytechnic, Kaura Namoda, Zamfara State, \\ Nigeria.
}

Author's Email: akamomoses@gmail.com 08063260014

\begin{abstract}
Sediments samples from three dams and rivers in Zamfara State were analyzed for chemical association of the metals $(\mathrm{Zn}, \mathrm{Cd}, \mathrm{Cr}, \mathrm{Pb}$ and $\mathrm{Hg})$ using sequential extraction method to determine the amount of the heavy metals available for absorption. The concentrations were determined in four fractions. The concentration of heavy metals in the food crop (tomatoes) was also determined using atomic absorption spectrometry (AAS). The sequential extraction was carried out using $(1.0 \mathrm{~g})$ of powder sample weighed into a glass centrifuge $(60 \mathrm{ml})$ and fractions were obtained. Comparing the way the metals were bound to the different fractions in the sediments, it showed clearly that the metals in the sediments are bound to different fractions with different strength. $\mathrm{Cd}$ and $\mathrm{Cr}$ were primarily in the carbonate bound fraction while $\mathrm{Zn}$ and $\mathrm{Hg}$ appear mainly in the residual phase. $\mathrm{Pb}$ was found in carbonate, exchangeable and water soluble fractions. The distribution of the five metals studied revealed their differences in mobility. From the five elements studied, Cd (14.739$39.931 \%)$ and $\mathrm{Pb}(0.105-9.832 \%)$ appeared to be the most readily solubilized, thus making these elements the most potentially bioavailable. This may present a real threat as $\mathrm{Cd}$ and $\mathrm{Pb}$ are transferred into the food chain from soil contaminated by these metals. $\mathrm{Zn}$ and $\mathrm{Cr}$ levels in the tomatoes, were within international standard while $\mathrm{Cd}(0.1022 \mathrm{mg} / \mathrm{l}), \mathrm{Pb}(0.2104 \mathrm{mg} / \mathrm{l})$ and $\mathrm{Hg}(1.8818 \mathrm{mg} / \mathrm{l})$ levels were far above $(0.01,0.01$ and $0.001 \mathrm{mg} / \mathrm{l})$ USEPA standard for drinking water. Two indices such as contamination factor (CF) and pollution load index (PLI) were used to calculate the contamination level of the tomatoes samples. The result showed a high contamination level for $\mathrm{Cd}, \mathrm{Pb}$ and $\mathrm{Hg}$ and a general high overall pollution load across all the locations.
\end{abstract}

Keywords: sediments, chemical speciation, dams, rivers, heavy metals

\section{INTRODUCTION}

Research showed that from natural aquatic environment, many chemical parameters are available in low concentration. This concentration increases as a result of rapid growth of population, increased urbanization, industrial activities and exploitation of natural resources (Mehedi et al., 1999). Pollution and contamination of natural water bodies by industrial discharge, agricultural practices and domestic activities have emerged as major challenges in a densely populated country like Nigeria. Contamination of the environment usually result from industrial activities, such as mining, electroplating, gas exhaust, energy and fuel production, fertilizer and pesticides application, and generation of municipal waste (Olaofe et al., 2004). Gold mining and processing have been the main sources of heavy metal contamination in the environment (Duruibe et al., 2007; Boamponsem et al., 2010; Girigisu et al., 2012). The uncontrolled dissemination of liquid waste to large water bodies has negatively impaired on both water quality and aquatic life (Abdulrahman et al., 2008). The processing of the ores for gold produces poisonous heavy metals substances such as oxides and sulphides that are released into the environment (Boamponsem et al., 2010). As a result, most of the water sources, particularly in Zamfara State, are gradually becoming polluted due to the addition of these foreign materials from the environment. Different aquatic organisms often respond to external contamination in different ways, where the quantity and form of the element in water, sediment, or food will determine the degree of accumulation (Abdulrahman et al., 2008; Olaoye and Onilude, (2009). Certain environmental conditions such as salinity, $\mathrm{pH}$, and water hardness can play an important factor in heavy metals accumulation up to toxic concentrations in living organisms and cause ecological damage (Garba et al., 2010). Thus, heavy metals acquired through the food chain as a result of pollution are potential chemical hazards that threaten consumers (Olaofe et al., 2004). Artisanal mining is a vital economic sector in many developing countries. However, limited financial resources and technical training, and the availability of cheap, but potentially hazardous methods of extraction and processing of minerals can cause major threats to both miners and the environment (Bitala, 2008; Armah et al., 2010). This is the experience in the mining locations in Zamfara State. At the peak of mining periods especially in Zamfara State, up to 5000 people invade the mining areas from within and outside the State. This usually produces devastating effects on health and environment. Surface waters in close proximity to the mining industries are at a great risk of contamination due to waste discharges from mining activities (UNEP, 2010). To assess the environmental impact of polluted sediments, information on metal concentrations alone is not enough to 
understand the environmental behavior of heavy metals available in different chemical form in the sediments (Stecko and Bendell -Young, 2000; Bendell - Young et al., 2002). Research on the distribution and separation of heavy metals in sediments can provide information on the degree of pollution and the actual environmental impact of metal bioavailability as well as their origin (Rauret et al., 1988; Lopez-Gonzales et al., 2006). The most labile are metals associated with water soluble ions, exchangeable and carbonate that can easily be remobilized by changes in environmental conditions such as $\mathrm{pH}$, salinity etc. (Perez et al., 1991). Therefore, a proper understanding of factors such as the mobility, transport rates, paths and sinks of sedimentary particles and associated contaminants will be necessary for predicting both the fate of substances that have been introduced into the dams and rivers as well as any risk associated with their presence.

\section{MATERIALS AND METHODS}

Sampling Points: The sampling area are in Zamfara State which is located in the North Western region of Nigeria between Latitude $11040^{\prime} \mathrm{E}$ and Longitudes $70025^{\prime} \mathrm{E}$ at an altitude of $420 \mathrm{~m}$. The dams are located in Gusau LGA (Gusau dam), Maradun LGA (Bakolori dam), and Maru LGA (Dangulbi dam). The rivers are located in Anka LGA of the state; they are Abare, Sunke and Bagega which are contaminated with lead poisoning coming from extensive gold mining in those villages.

Sample Collection and Analysis: About $1.0 \mathrm{~kg}$ of the sediment samples was collected at three different points in a location and five meters away from each other to form a composite sample. Samples were collected by scooping the topmost layer sediments using a plastic spoon and then stored in a pre-cleaned $1000 \mathrm{ml}$ polyethylene container, labeled and taken to the laboratory for storage in freezers awaiting analysis. Samples were then air dried in the laboratory and crumbs in the sediment were removed. Sediments were also sieved through a $2 \mathrm{~mm}$ sieve to remove coarse particles.

Water soluble fractions: Approximately (1.0 g) sediment sample that has been air dried was weighed into a polythene container $(60 \mathrm{ml})$; water $(10 \mathrm{ml})$ was added and shaken for 1 hour. The soil colloids were then centrifuged a Baird and TatLock authobench centrifuging machine at $4000 \mathrm{rpm}$ for 20 min. The supernatant was decanted and filtered through a Whatman No.42 filter paper into a volumetric flask $(50 \mathrm{ml})$, which was then made up to the mark with water.

Exchangeable fraction: To the residual soil sample from F1, $(10 \mathrm{ml})$ of $\mathrm{MgCl}_{2}(1.0 \mathrm{~mol} / \mathrm{l})$ at $\mathrm{pH} 7$ for one hour with continuous agitation using magnetic stirrer.

Carbonate -bound fraction: To the residue obtained above. An aliquot $(8 \mathrm{ml})$ sodium acetate $(10 \mathrm{~mol} / \mathrm{l})(\mathrm{pH}=5.0$, adjusted with acetic acid) was added while Continuous agitation was sustained for 5 hours.

Residual fraction: The residue from above step was digested with a 5:1 mixture of hydrofluoric and per chloric acids. The sediment was first digested in a platinum crucible with a solution of concentrated $\mathrm{HClO}_{4}(2.0 \mathrm{ml})$ and $\mathrm{HF}(10.0 \mathrm{ml})$ to near dryness; subsequently a second addition of $\mathrm{HClO}_{4}(1.0 \mathrm{ml})$ and $\mathrm{HF}(10.0 \mathrm{ml})$ was made and again the mixture was evaporated to near dryness. Finally, $\mathrm{HClO}_{4}(1.0 \mathrm{ml})$ alone was added and the sample was evaporated until the appearance of white fumes. The residue was dissolved in $\mathrm{HCl}(12.0 \mathrm{~mol} / \mathrm{l})$ and diluted to $25.0 \mathrm{ml}$. The resulting solution was then analyzed by flame atomic absorption spectrophotometry for metal using standard addition technique. About $(1.0 \mathrm{~g})$ of grounded tomatoes sample was weighed into beaker $(100.0 \mathrm{ml})$. Concentrated $\mathrm{HNO}_{3}(5.0 \mathrm{ml})$ and perchloric acid $(2.0 \mathrm{ml})$ was added and heated in a fume cupboard to almost dryness. Then, distilled water $(10.0 \mathrm{ml})$ was added and the solution was properly stirred and filtered with a whatman filter paper No. 42. The filtrate of the digestate was then transferred into bottle $(50.0 \mathrm{ml})$ and was then made up to mark with distilled water (APHA, 2005). Blank samples were prepared in the same procedure with distilled water.

Statistical Analysis: Descriptive statistics (such as mean and standard deviation) were performed on all the data. Duncan Multiple Range Test was used to separate means where significant. Means were considered significantly different at $\mathrm{P}>$ 0.05 . 
RESULT AND DISCUSSION

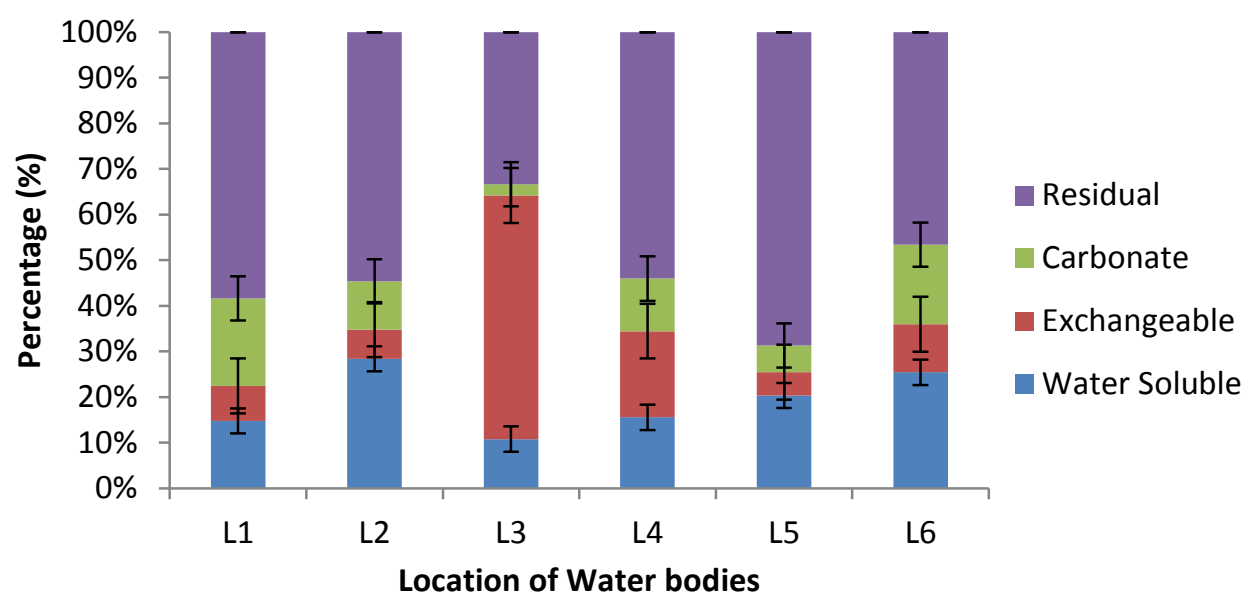

Fig. A Percentage $\mathrm{Zn}$ in different chemical fractions across all locations

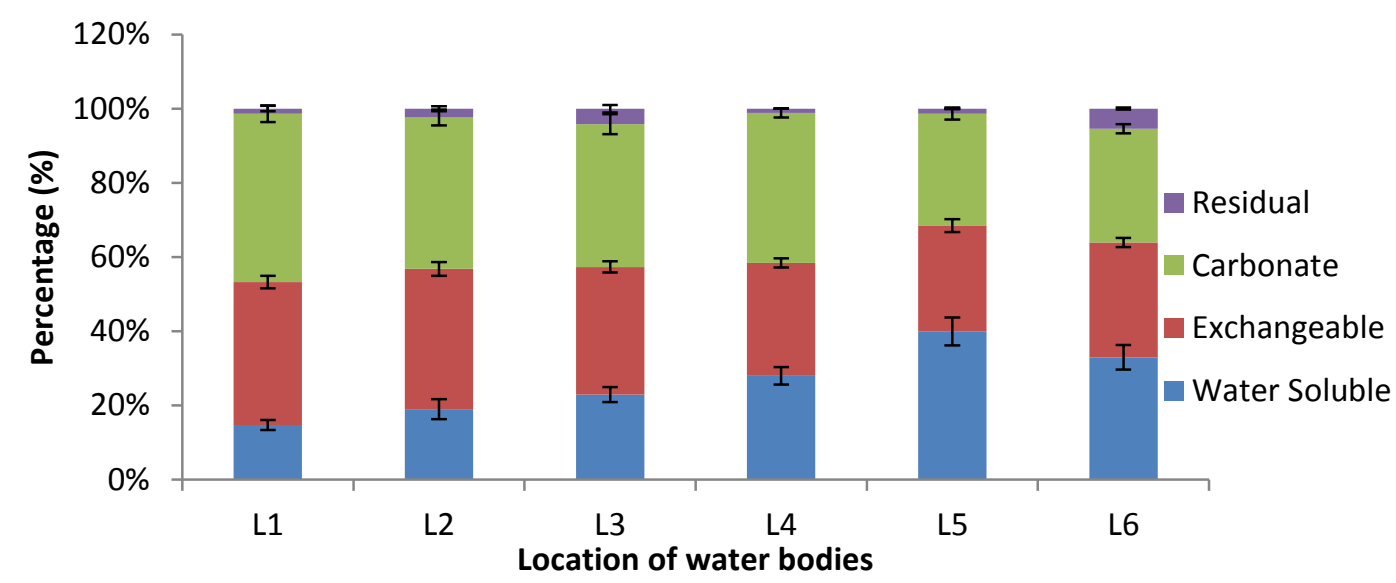

Fig. B Percentage Cd in different chemical fractions across all locations

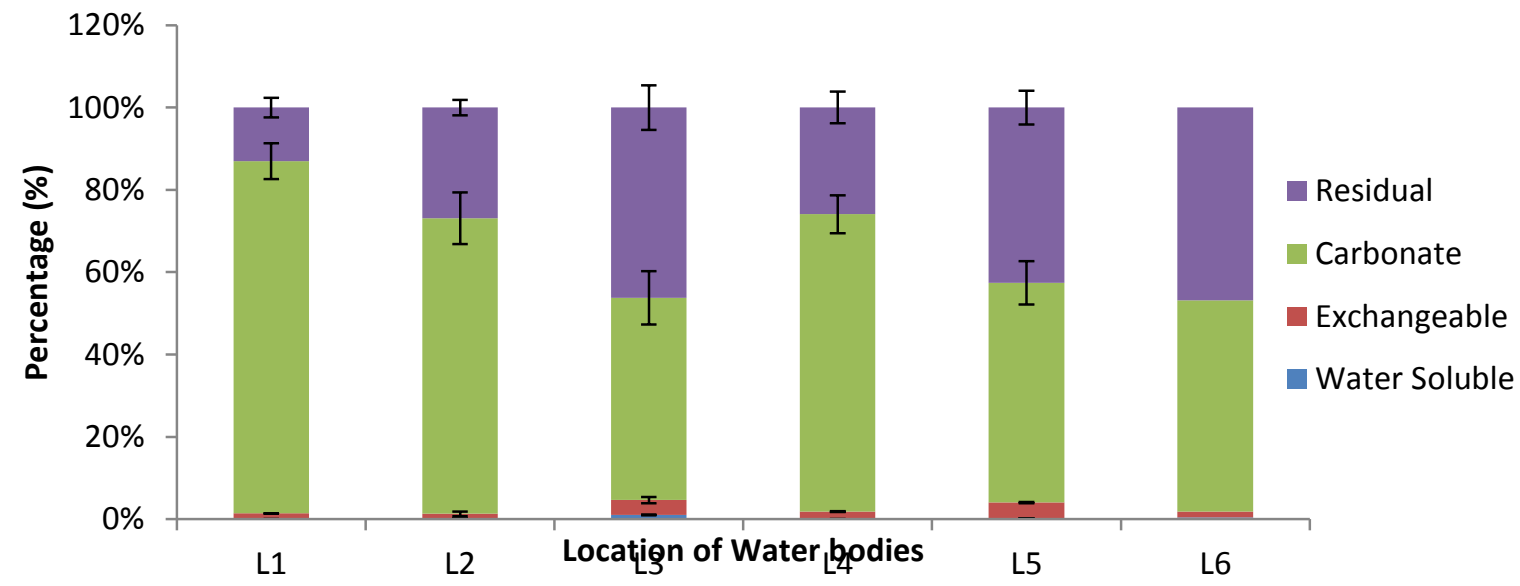

Fig. C Percentage $\mathrm{Cr}$ in different chemical fractions across all locations 


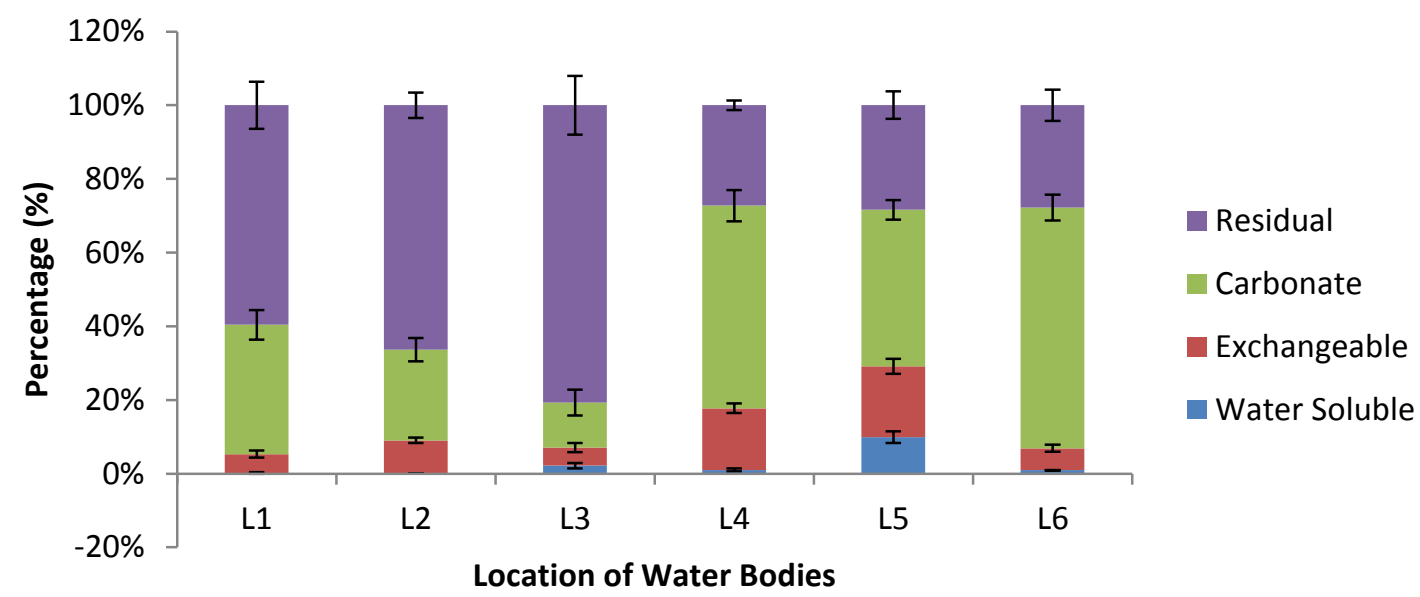

Fig. D: Percentage $\mathrm{Pb}$ in different chemical fractions across all locations

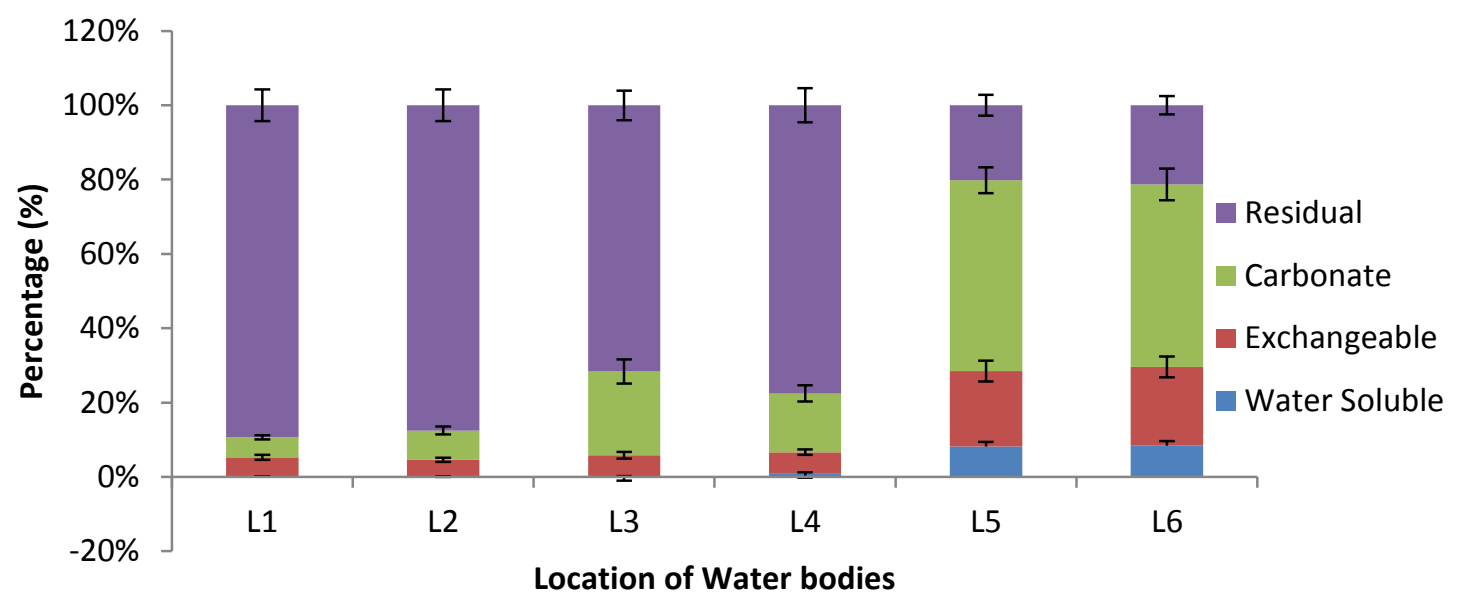

Fig. E: Percentage $\mathrm{Hg}$ in different chemical fractions across all locations

Key:

L1

$\mathbf{L 3}$

L5

Gusau dam
Dangulbi dam
Sunke river

The chemical fractionation of $\mathrm{Zn}, \mathrm{Cr}, \mathrm{Cd}, \mathrm{Pb}$ and $\mathrm{Hg}$ in the sediments from all the dams and rivers under studied in the state are as presented in percentage starck graph in Fig. A---E. The three chemical fractions that constitute the non-residual fraction considered in this work are defined operationally as water soluble (F1), exchangeable (F2) and carbonate bound (F3) while the residual fraction is defined as F4. It was generally observed that the carbonate bound fraction (F3) recorded high $\mathrm{Cr}$ percentages across all the location with exception of location

\section{L2 Bakolori dam \\ L4 Bagega River \\ L6 Abare River}

$\mathrm{L} 3$, which recorded its highest percentage $\mathrm{Cr}$ in the residual fraction. The water soluble fraction $\mathrm{F} 1$ consistently recorded very low (below $1.5 \%$ ) percentage fraction of $\mathrm{Cr}$ across all the six locations studied. It was generally observed that predominant percentage $\mathrm{Hg}$ was recorded in the residual fraction across all the location with exception of Sunke (51.316\%) and Abare rivers (49.145\%) with high percentage $\mathrm{Hg}$ in the carbonate bound fraction. Water soluble fraction generally recorded very low percentage $\mathrm{Hg}$ across all the locations. 
Table 1: Concentrations of Heavy Metals $(\mathrm{mg} / \mathrm{kg})$ in Tomatoes Samples for Two wet Seasons

\begin{tabular}{lllllll}
\hline location & year & $\mathrm{Zn}$ & $\mathrm{Cd}$ & $\mathrm{Cr}$ & $\mathrm{Pb}$ & $\mathrm{Hg}$ \\
$\mathrm{L} 1$ & 2014 & $0.029 \pm 0.002$ & $0.019 \pm 0.001$ & $0.183 \pm 0.003$ & $0.261 \pm 0.004$ & $0.556 \pm 0.002$ \\
& 2015 & $0.024 \pm 0.002$ & $0.010 \pm 0.002$ & $0.010 \pm 0.004$ & $0.334 \pm 0.001$ & $1.746 \pm 0.003$ \\
L2 & 2014 & $0.039 \pm 0.001$ & $0.019 \pm 0.003$ & $0.261 \pm 0.003$ & $0.125 \pm 0.002$ & $0.163 \pm 0.000$ \\
& 2015 & $0.049 \pm 0.001$ & $0.012 \pm 0.002$ & $0.012 \pm 0.003$ & $0.396 \pm 0.001$ & $2.202 \pm 0.003$ \\
L3 & 2014 & $0.052 \pm 0.002$ & $0.014 \pm 0.001$ & $0.157 \pm 0.004$ & $0.271 \pm 0.002$ & $0.446 \pm 0.000$ \\
& 2015 & $0.056 \pm 0.003$ & $0.016 \pm 0.005$ & $0.016 \pm 0.002$ & $0.511 \pm 0.002$ & $0.600 \pm 0.003$ \\
L4 & 2014 & $0.044 \pm 0.002$ & $0.032 \pm 0.001$ & $0.157 \pm 0.003$ & $0.021 \pm 0.004$ & $0.953 \pm 0.000$ \\
& 2015 & $0.048 \pm 0.002$ & $0.019 \pm 0.002$ & $0.019 \pm 0.004$ & $0.386 \pm 0.001$ & $1.050 \pm 0.003$ \\
L5 & 2014 & $0.092 \pm 0.001$ & $0.017 \pm 0.003$ & $0.118 \pm 0.003$ & $0.208 \pm 0.002$ & $\mathrm{ND}$ \\
& 2015 & $0.097 \pm 0.001$ & $0.019 \pm 0.002$ & $0.019 \pm 0.003$ & $0.188 \pm 0.001$ & $1.103 \pm 0.003$ \\
L6 & 2014 & $0.128 \pm 0.002$ & $0.027 \pm 0.001$ & $0.301 \pm 0.004$ & $0.356 \pm 0.002$ & $\mathrm{ND}$ \\
& 2015 & $0.124 \pm 0.003$ & $0.022 \pm 0.005$ & $0.022 \pm 0.002$ & $0.396 \pm 0.002$ & $0.896 \pm 0.003$ \\
\hline
\end{tabular}

Key: ND: not detected

Table 2: Concentrations of Heavy Metals $(\mathrm{mg} / \mathrm{kg})$ in Tomatoes Samples for Two dry Seasons

\begin{tabular}{lllllll}
\hline location & year & $\mathrm{Zn}$ & $\mathrm{Cd}$ & $\mathrm{Cr}$ & $\mathrm{Pb}$ & $\mathrm{Hg}$ \\
Gusau & 2014 & $0.036 \pm 0.002$ & $0.432 \pm 0.001$ & $0.364 \pm 0.003$ & $0.250 \pm 0.004$ & $\mathrm{ND}$ \\
& 2015 & $0.031 \pm 0.002$ & $0.256 \pm 0.002$ & $0.369 \pm 0.004$ & $0.365 \pm 0.001$ & $4.363 \pm 0.003$ \\
Bakolori & 2014 & $0.058 \pm 0.001$ & $0.216 \pm 0.003$ & $0.324 \pm 0.003$ & $1.074 \pm 0.002$ & $\mathrm{ND}$ \\
& 2015 & $0.041 \pm 0.001$ & $0.334 \pm 0.002$ & $0.314 \pm 0.003$ & $0.500 \pm 0.001$ & $2.527 \pm 0.003$ \\
Dangulbi & 2014 & $0.093 \pm 0.002$ & $0.668 \pm 0.001$ & $1.165 \pm 0.004$ & $0.615 \pm 0.002$ & $\mathrm{ND}$ \\
& 2015 & $0.071 \pm 0.003$ & $0.354 \pm 0.005$ & $1.150 \pm 0.002$ & $0.644 \pm 0.002$ & $1.343 \pm 0.003$ \\
Bagega & 2014 & $0.059 \pm 0.002$ & $0.668 \pm 0.001$ & $0.199 \pm 0.003$ & $0.354 \pm 0.004$ & $\mathrm{ND}$ \\
& 2015 & $0.061 \pm 0.002$ & $0.472 \pm 0.002$ & $0.099 \pm 0.004$ & $0.394 \pm 0.001$ & $1.362 \pm 0.003$ \\
Sunke & 2014 & $0.166 \pm 0.001$ & $0.729 \pm 0.003$ & $0.126 \pm 0.003$ & $0.511 \pm 0.002$ & $\mathrm{ND}$ \\
& 2015 & $0.113 \pm 0.001$ & $0.098 \pm 0.002$ & $0.116 \pm 0.003$ & $0.521 \pm 0.001$ & $1.188 \pm 0.003$ \\
Abare & 2014 & $0.420 \pm 0.002$ & $0.256 \pm 0.001$ & $0.314 \pm 0.004$ & $0.394 \pm 0.002$ & $\mathrm{ND}$ \\
& 2015 & $0.293 \pm 0.003$ & $0.491 \pm 0.005$ & $0.334 \pm 0.002$ & $0.719 \pm 0.002$ & $1.293 \pm 0.003$ \\
\hline
\end{tabular}

Key: ND: not detected

Heavy Metals in Tomatoes Samples: The results obtained for metals in tomatoes samples from all locations around the dams and rivers in study area are presented in Table 1 and 2. Generally, the concentrations of $\mathrm{Cr}$ in the dry seasons were higher than in the wet season, a situation which suggests seasonal variation effect also the concentrations of $\mathrm{Pb}$ in the dry seasons were higher than in the wet season, a situation which equally suggests seasonal variation effect. However, it was generally observed that $\mathrm{Hg}$ concentrations are higher in the dry seasons than their corresponding wet seasons. While the concentration of $\mathrm{Hg}$ was mostly below detection limit but very pronounced concentration in year 2015 . 
Table 3: Correlation matrix of Heavy Metals Concentrations (mg/kg) in Tomatoes Samples for Two Wet and Two Dry Seasons

\begin{tabular}{|c|c|c|c|c|c|c|c|c|c|c|}
\hline & Correlations & For wet & & & & Correlations & For dry & & & \\
\hline & Zn & Cd & $\mathrm{Cr}$ & $\mathbf{P b}$ & Hg & $\mathbf{Z n}$ & Cd & $\mathrm{Cr}$ & $\mathbf{P b}$ & Hg \\
\hline $\begin{array}{l}\mathrm{Zn} \\
\mathrm{Cd}\end{array}$ & $\begin{array}{c}1 \\
.416^{*}\end{array}$ & 1 & & & & $\begin{array}{c}1 \\
.416^{*}\end{array}$ & 1 & & & \\
\hline $\mathrm{Cr}$ & .128 & $.471^{* *}$ & 1 & & & .128 & $.471^{* *}$ & 1 & & \\
\hline $\mathbf{P b}$ & .166 & $-.350^{*}$ & $.429^{* *}$ & 1 & & .166 & $-.350^{*}$ & $.429^{* *}$ & 1 & \\
\hline \multirow[t]{2}{*}{ Hg } & $-.375^{*}$ & $-.414^{*}$ & $.709^{* *}$ & .277 & 1 & $-.375^{*}$ & $-.414^{*}$ & $\begin{array}{c}- \\
.709^{* *}\end{array}$ & .277 & 1 \\
\hline & 36 & 36 & 36 & 36 & 36 & 36 & 36 & 36 & 36 & 36 \\
\hline
\end{tabular}

Assessment of Heavy Metal Pollution in Tomatoes Samples: Contamination factor calculated for heavy metal concentration in tomatoes are presented in Table 4. It revealed that only $\mathrm{Hg}$ had contamination factor $(\mathrm{CF}>>6)$ higher than 6 across all the location for both wet and dry seasons. The pollution load indices (PLI) for all the locations have values less than one (1) for both wet and dry season.

Table 4: Heavy Metal Contamination Factors (CF) and Pollution Load Index (PLI) in Tomatoes for Wet and Dry Seasons.

\begin{tabular}{lllllll} 
Location/Wet & $\mathrm{Zn}$ & $\mathrm{Cd}$ & $\mathrm{Cr}$ & $\mathrm{Pb}$ & $\mathrm{Hg}$ & $\mathrm{PLI}$ \\
Gusau & 0.0026 & 0.1050 & 0.0029 & 0.0383 & 6.1667 & 0.0453 \\
Bakolori & 0.0005 & 0.0443 & 0.0016 & 0.0164 & 6.0033 & 0.0206 \\
Dangulbi & 0.0006 & 0.0653 & 0.0018 & 0.0354 & 2.4000 & 0.0225 \\
Bagega & 0.0024 & 0.1117 & 0.0026 & 0.0368 & 3.0500 & 0.0378 \\
Sunke & 0.0013 & 0.0733 & 0.0010 & 0.0159 & 12.7800 & 0.0283 \\
Abare & 0.0017 & 1.8083 & 0.0057 & 0.0526 & 10.3000 & 0.0992 \\
Gusau & 0.0053 & 1.5733 & 0.0132 & 0.1108 & 10.7567 & 0.1671 \\
Bakolori & 0.0015 & 2.4250 & 0.0054 & 0.0204 & 2.9867 & 0.0662 \\
Dangulbi & 0.0011 & 1.2450 & 0.0069 & 0.0430 & 8.5833 & 0.0915 \\
Bagega & 0.0029 & 2.4233 & 0.0143 & 0.1341 & 3.7967 & 0.1384 \\
Sunke & 0.0019 & 1.5400 & 0.0023 & 0.0199 & 12.7100 & 0.0705 \\
Abare & 4.1895 & 2.7166 & 0.0091 & 0.0862 & 11.4330 & 0.6328 \\
\hline
\end{tabular}

ND: Below detection

\section{Chemical Speciation of Metals in Sediment}

Zinc: The distribution of $\mathrm{Zn}$ obtained in the four fractions by the extraction of sediment across all the six locations showed that $\mathrm{Zn}$ was mostly concentrated in the water soluble (FI) with the highest percentage of $28 \%$ in Bakolori dam and the least at Dangulbi dam (10.765\%). The highest percentage concentration of $\mathrm{Zn}$ in the exchangeable was recorded in Dangulbi dam while Bakolori dam recorded the lowest level. The predominance of percentage $\mathrm{Zn}$ was mostly recorded in the residual fraction. This suggests that the greater percentage of $\mathrm{Zn}$ in the sediments is non-bioavailable. Literature revealed that High percentage of total $\mathrm{Zn}$ have been found to be associated with the reducible fraction in similar studies of polluted sediments, which was not determined in this present work (Fernandes, 1997; Li et al., 1995; Fan et al., 2002; Korfali and Davies 2004). The absorption of $\mathrm{Zn}$ onto oxides has higher stability constants than onto carbonates (Rao et al., 1990). Several other works have also revealed that $\mathrm{Zn}$ is more associated with exchangeable and $\mathrm{Fe}$ Mn oxides (Kuo et al., 1983; Ramos et al., 1994) which is consistent with the result of this wok. Cadmium: The predominant percentages of $\mathrm{Cd}$ were recorded in the carbonate bound fraction of Gusau dam $45.424 \%$, Bakolori dam $40.820 \%$, Dangulbi dam $38.446 \%$ and Bagega river $40.512 \%$. The residual fraction generally recorded low $\mathrm{Cd}$ concentration across all the locations. This further suggests that a high concentration of $\mathrm{Cd}$ in this sediment might be easily available and can easily enter the food chain. This is in close agreement with the report of Ahumada et al., 1999; Narwal et al., 1999 who reported that $\mathrm{Cd}$ is distributed more as carbonate, reducible and as residual fraction. High concentrations of $\mathrm{Cd}$ in carbonate bound fractions have also been reported in sediments (Rao et al., 1990; Korfali and Davies, 2004). The result obtained in this work were in accordance with previous studies by Adelakan $e t$ al., 2011 who highlighted that the potential risks caused by $\mathrm{Cd}$ were extremely associated with the acid-soluble fractions.

Chromium: Cr recorded the highest percentage level in the carbonate bound fraction across all the locations with exception of Dangulbi dam. The lowest percentage was generally recorded 
SPECIATION OF METALS IN SEDIMENTS ...

in the water soluble fraction across all the six locations. This suggests that $\mathrm{Cr}$ was mostly concentrated in the carbonate bound fraction $(72.234 \%)$ much more than its concentration in exchangeable fraction (1.828\%). The residual fraction has concentration of $171.2 \mathrm{mg} / \mathrm{kg}$ i.e. about $25.937 \%$ while water soluble has the least value. This is consistent with reports of other researchers where large proportion of $\mathrm{Cr}$ was found in the carbonate bound fraction and the least fraction located in the water soluble fraction (Korfali and Davies, 2004; Naimo et al., 2005). Chromium may not be easily mobilized, this is because of the small fraction found in the exchangeable phase (F2), and hence a more severe condition might be required for their released. This result was also in agreement with previous studies that the potential risks caused by $\mathrm{Cr}$ were extremely associated with acid - soluble fractions (Adelakan et al., 2011). However, the potential ecological risks that still exist which cannot be ignored even with the attendant low percentage degree of association with the mobile fraction (Adelakan et al., 2011).

Lead: The exchangeable fraction recorded some appreciable amount of $\mathrm{Pb}$ across all the locations with the highest being (16.714\%) at Bagega river. The percentage of $\mathrm{Pb}$ distribution is in order: F3>F2 $>>F 1$. This is consistent with the results obtained by several authors (Jones and Turki, 1997; Li et al., 1995; Fan et al., 2002; Adelakan et al., 2011 and Wong et al., 2007).

Mercury: All three dams considered in this work and Bagega River recorded their highest percentage $\mathrm{Hg}$ concentration in the residual fraction while Sunke and Abare River recorded their highest percentage fractions in the carbonate bound fraction. The exchangeable also had some appreciable percentage $\mathrm{Hg}$ concentration across all the six locations. Water soluble fraction consistently had the lowest percentage $\mathrm{Hg}$ concentration across all the locations. Korfali and Davies, 2004; Naimo et al., 2005 suggests that the mercury metal fractions are more associated with the alumino-silicate minerals. The relative metal concentration in non-residual fraction can be used as a measure of the contribution from natural and anthropogenic sources, including higher percentage in these fractions revealed a high level in pollution of sediments from the sampling zones (Cao et al., 2014). Comparing the way the metals were bound to the different phases in the sediments, $\mathrm{Cd}$ and $\mathrm{Pb}$ appeared to be the most readily solubilized, thus making these elements the most potentially bioavailable. This may present a real threat as $\mathrm{Cd}$ is transferred into the food chain from soil contaminated by this metal. It is also clear that from the results and discussion so far that the metals in the sediments are bound to different fractions with varying strength (Duan et al., 2014).

\section{Heavy Metals Content in Food Crop (Tomatoes)}

Correlation analysis conducted to examine whether there is a relationship between the heavy metal concentrations in the tomatoes revealed a significant positive relationship for $\mathrm{Cr}$ and $\mathrm{Cd}, \mathrm{Cd}$ and $\mathrm{Zn}, \mathrm{Hg}$ and $\mathrm{Pb}$ in the wet season and a significant and positive relationship for $\mathrm{Cr}$ and $\mathrm{Cd}$, and $\mathrm{Pb}$ and $\mathrm{Cr}$ in the dry season. This may suggest reason for the consistent variation of these metals in all the locations across the seasons. Concentrations of heavy metal in tomatoes in this work revealed spatial variation at all locations during the study periods. The relative abundance of different metals at the six locations during the wet and dry seasons varied with locations and with season in the tomatoes samples.

Zinc: All the metals investigated except $\mathrm{Zn}$ were measured in relatively high amount especially during the dry seasons across all the locations. This situation above is expected in view of the reduction in the pollution in the wet season arising from the increased dilution and water flow. Heavy metals are found naturally in the Earth, and they become concentrated as a result of human activities which include but not limited to industrial processes, mining, agriculture and transportation (Noor-ul et al., 2015; Bassey et al., 2014). These metals have both positive and negative roles in human life (Noor-ul et al., 2015, Colak et al., 2005; Oktem et al., 2005).

Cadmium: Heavy metals such as $\mathrm{Cd}, \mathrm{Cu}, \mathrm{Pb}, \mathrm{Cr}, \mathrm{Zn}, \mathrm{Ni}, \mathrm{As}$, $\mathrm{Co}$ and $\mathrm{Hg}$ cannot be degraded or destroyed and can be accumulated in living tissue through the food chain, causing various diseases and disorders (Manohara et al., 2014). Fruits, vegetables and other foods are among pathways by which heavy metals enter the human tissues leading to deterioration of health (Manohara et al., 2014). The presence and accumulation of the analyzed heavy metals in tomatoes plants could be traced to their presence in the wastes water used for their irrigation. Liu et al., 2005 opined that the soil type, root stock, mulching, irrigation, fertilization, and other cultural practices has an influence on the amount of water and nutrient supply to plant and therefor affect the composition and quality attributes of the harvested plants.

Chromium: The result of this study agreed with the data reported by Liu et al., (2005). Also report from some researchers (Muchuweti et al., 2006; Sharma et al., 2007) demonstrated that the plants grown on wastewater-irrigated soils are contaminated with heavy metals and that they pose a threat to health. The accumulation of these heavy metals in the tomatoes was as a result of the presence of the metals in the soil due to their irrigation with waste water.

Lead: The concentration of $\mathrm{Pb}$ in this study was in agreement with the submission of Liu et al., 2005 who opined that the extractable $\mathrm{Pb}$ in both cultivated and uncultivated soils increased by increasing $\mathrm{Pb}$ concentration to the soil. Sharma et al. (2007) showed that the concentrations of exhaustible metals such as $\mathrm{Zn}, \mathrm{Cd}$, and $\mathrm{Pb}$ in the soil increased with increase in sludge application. This was supported by the submission of Sharma et al. (2007) who find a highly significant correlation between the chemical composition of irrigation water used and the soil chemical properties. The calculated contamination factor $(\mathrm{CF})$ revealed that only $\mathrm{Hg}$ had $\mathrm{CF}$ values greater 6, which indicates a serious contamination of tomatoes harvested from all the location. The pollution load index (PLI) across all the locations had PLI values less than 1 . This indicates that there is no serious overall pollution load on the tomatoes samples.

Conclusion: The speciation of heavy metals with selective extracting agents gives additional information about the fundamental reactions governing the behaviour of the metals in sediments. Comparing the way the metals were bound to the 
SPECIATION OF METALS IN SEDIMENTS ...

different fractions in the sediments, it is clear that the metals in the sediments are bound to different fractions with different strength. Anthropogenic input of $\mathrm{Cd}$ and $\mathrm{Cr}$ was primarily in the carbonate bound fraction while Inputs of $\mathrm{Zn}$ and $\mathrm{Hg}$ appear mainly in the residual form. Inputs of $\mathrm{Pb}$ were found in carbonate, exchangeable and water soluble fractions. The distribution of the five studied metals in the various fractions confirms their differences in mobility. Of the five elements studied, $\mathrm{Cd}$ and $\mathrm{Pb}$ appeared to be the most readily solubilized, thus making these elements the most potentially bioavailable. This may present a real threat as $\mathrm{Cd}$ and $\mathrm{Pb}$ are transferred into the food chain from soil contaminated by these metals.

\section{REFERENCES}

Adelakan B A, Abegunde K D (2011). Determination of heavy metals concentrations in soil samples of ilaro- river. International Journal Phys. Sci. 6:1045-1058.

Ahumada, I., J. Mendoza, E. Navarrete and L. Ascar, (1999). Sequential extraction of heavy metals in soils irrigated with wastewater. Commun. Soil Sci. Plant Anal., (30): 1507-1519.

American Public Health Association, (APHA) 2005, "Standard Methods for the Examination of Water and Wastewater," 21st Edition American Public Health Association, p.117.

Armah F A, Obiri S, Yawson D O, Pappoe A N M, Bismark A (2010). Mineral Comodity profiles-Gold. Journal Environ Stat (1):212-218.

Bassey, F.I Iwegbue C.M.A., Obi-Iyeke, G.E., Tesi G.O., Rotu, A.R., Gobe, O.A and Tsafe A.I., (2014). Heavy metals in soils and tomatoes grown in urban fringe environment in Asaba, Delta state, Nigeria. Nigerian Journal of Basic and Applied Science, 22 (1\&2): pp. 27-31.

Bendell-Young L.I., Dutton M. and Pick F.R (2002). Contrasting two methods for determining trace metal partitioning in oxidizable sediments. Biogeochemistry (17): 1529.

Bitala M F (2008). Heavy metals in the environments. University of Dares Salaam. pp 1-61.

Boamponsem, L. K, Adam, J. I, Dampare, S .B, Owusu-Ansah, E and Addae G (2010). Heavy metals in the estuary. Journal Chem. Pharm. Res. 2: 504-527.

Cao, H.; Chen, J. and Zhang, J. (2010). Heavy metals in rice and garden vegetables and their potential health risks to inhabitants in the vicinity of an industrial zone in Jiangsu, China. Journal. Environ. Sci., (22): 1792-1799.

Duan, D.D.; Ran, Y.; Cheng, H.F.; Chen, J.A.; Wan, G.J. (2014). Contamination trends of trace metals. Marine Pollution Bulletin, (44): 816-832.
Duruibe, T. O, Ogwuegbu, M. O. C, Egwurugwu, J. N (2007). Heavy metals in the Delta river. International Journal Phys. Sci. (2): 112-118.

Fan, W., Wang W.X., Chen J., Li, X.D. and Yen. Y.F. (2002), $\mathrm{Cu}$. $\mathrm{Ni}$ and $\mathrm{Pb}$ speciation in surface sediment from a contaminated bay of northern China. Marine Pollution Bulletin, (44): 816-832.

Fernandes H.M (1997). Heavy Metal distribution in sediment and ecological risk assessment: the role of digenetic processes in reducing metal toxicity in bottom sediments. Environmental Pollution. 97: 317-325.

Garba Z.N., Hamza, S.A and Galadima, A. (2010) Arsenic level speciation in fresh water from Karaye Local Government Area, Kano State, Nigeria. International Journal of Chemistry, India, (4): 113-117.

Girigisu S, Ibeanu I G E, Adeyemo D J, Okoh S (2012). Metal pollution in aquatic environment. American Journal Appl. Sci. (9): 1014-1019.

Korfali S.I and Davies B.E (2004). Speciation of metal in sediment and water in a river underline by limestone role of earbonate species for purification capacity of rivers Advanced Environmental Research, 8: 599-612.

Kuo S. and Baker A.B. (1983). Distribution and forms of copper, Zinc, Cadmium, Iron and Manganese in soils near a copper smelters. Soil Science, 135: 101-9.

Li X., Coles B.J., Ramsey, M.H. and Thornton I. (1995b). Chemical partitioning of the new National Institute of Standards and Technology Reference Materials (SRM 2709-2711) by sequential extraction using inductively coupled plasma atomic emission spectrometry. Analyst, 120: 1415-1419.

Lopez-Gonzalez N., Borrego J., Morales J.A., Carro O. and Lazano-Soria O. (2006). Metal fractionation in toxic sediments of an estuary affected by acid mine drainage (southwestern Spain). Estuary and Coastal Shelf Science. 68: 297-304.

Manohara, B. and Belagali, S.L., (2014). Characterization of essential nutrient and heavy metals during municipal solid waste composting International Journal of Innovative Research in Science, Engineering and Technology, 3 (2): p. 9664-9672.

Medhi, S; Deka, M.; Sarma M.P.; Bhattacharjee, M.; Ghazanavi Idris M.D. and Ahmed, G.(2012). High content of aflatoxin in the indigenous foods as a possible risk factor for liver cancer: An experience from Assam, India, Journal. Environ. Res. Develop., 7(2A):838-843,

Muchuweti, M.J., Birkett, J.W., Chinyanga, E., Zvauya, R., Scrimshaw, M.D., and Lester, 
SPECIATION OF METALS IN SEDIMENTS ...

Muraleedharan V, Antony KP, Perigreen PA, Gopakumar K (2006). Utilization of unconventional fish resources for surimi preparation. Proceedings of the second workshop on scientific results of FORV SAGAR. Sampada. Dept. of Ocean development. New Delhi, (India). pp. 539-543.

Naimo D., Adamo P., Imperato M. and Stanzione D. (2005). Mineralogy and geochemistry of a marine sequence. Gulf of Salerno, Italy. Quaternary International, 53-63.

Narwal, R.P., B.R. Singh and B. Salbu, (1999). Association of cadmium, zinc, copper and nickel with components in naturally heavy metal-rich soils studied by parallel and sequential extractions. Commun. Soil Sci. Plant Anal., 30: 1209-1230.

Noor-ul, A. and Tauseef A., (2015). Contamination of Soil with heavy metals from industrial effluent and their translocation in green vegetables of Peshawar, Pakistan RSC Advances, p. 14322 - 14329 .

Oktem, F., Yavrucuoglu, H., Turedi, A. and Tune, B., (2005). The effect of nutritional habits on hematological parameters and trace elements in children. SuleymanDemirel Univ.

Fak.Der. (12): 6-10.

Olaoye, O.A., A.A., Onulide (2009) Assessment of Microbial quality of sachet-packaged drinking water in western Nigeria and its public health significance. Public Health, 123: 729-734.

Oshodi, A.A, Olaofe O. and Hall, G.M (1993): Amino Acid, Fatty acid and mineral composition of Pigeon Pea (Cajanus Cajan). International Journal of Food Science and Nutriiton 43:187-191.

Perez M., Usero J. and Garcia I. (1991). Trace metals in sediments from Ria de Huelva. Toxic and Environmental Chemistry, 31: 275-283.
Ramos I. Ilernandez, L. M., and Gonzalez. M.J (1994). Sequential extraction of copper, lead, cadmium and zinc in the soil from or near Donana National, Park. Journal of Environmental Quality, 63: 50-57.

Rao C.H.M, and Murty, P.S.N. (1990). Geochemistry of the continental margin sediments of the central west coast of India. Journal of Geological Society of India, 35: 19-37.

Rauret G., Rubio, R., Lopez-Sanchez, J.F. and Casassas, E. (1988). Determination and speciation of copper and lead in sediments of a Mediternean river (River Tenes. Catalonia, Spain). Water Resource, 22: 449-455.

Sharma, R.K., Agrawal, M., and Marshall, F. (2007). Heavy metal contamination of soil and vegetables in suburban areas of Varanasi, India. Ecotoxicol. Environ. Safety. Journal. Doi:101016/jecenv

Stecko J.R.P. and Bendell-Young, L.I (2000). Contrasting the geochemistry of suspended particulate matter and deposited sediment within an estuary. Applied Geochemistry, 15: 735-775.

Tessier, A; Campbell, P.G.C and Blosson, M. (1979). Sequential extraction procedure for the speciation of particulate trace metals. Analytical Chemistry, 51(7): 844-851.

UNEP. (2010). Clearing the waters. A focus of water quality solutions. Nursing times. P. 99, http://www.unep.org/PDF/Clearing_the_Waters.pdf. 04/06/2016.

Wong, C.S.C., Wu, S.C., Duzgoren-Aydin, N.S., Aydin, A. and Wong, M.H (2007). Trace metals contamination of sediments in an e-waste processing villages in China. Environmental Pollution, 145: 434-442. International license viewed via https://creativecommons.org/licenses/by/4.0/ which permits unrestricted use, distribution, and reproduction in any medium, provided the original work is cited appropriately. 